\title{
Local Corrosion of Martensitic Stainless Steels during Exposure to Saline Aquifer Water and $\mathrm{CO}_{2}$ Environment
}

\author{
Anja Pfennig and Axel Kranzmann
}

\begin{abstract}
Carbon Capture and Storage (CCS) is well acknowledged to mitigate climate change. Therefore, pipe steels suitable for CCS technology require resistance against the corrosive environment of a potential CCS-site, e.g. heat, pressure, salinity of the aquifer, $\mathrm{CO}_{2}$-partial pressure. Samples of different mild and high alloyed stainless injection-pipe steels partially heat treated: 42CrMo4, X20Cr13, X46Cr13, $\mathrm{X} 35 \mathrm{CrMo} 4$ as well as $\mathrm{X} 5 \mathrm{CrNiCuNb16}-4$ were kept at $\mathrm{T}=60^{\circ} \mathrm{C}$ and ambient pressure as well as $p=100$ bar for $700 \mathrm{~h}-8000 \mathrm{~h}$ in a $\mathrm{CO}_{2}$-saturated synthetic aquifer environment similar to possible geological on-shore CCS-sites in the northern German Basin. Main corrosion products analysed on pits are $\mathrm{FeCO}_{3}$ and $\mathrm{FeOOH}$. The carbon content does not show significant influence on the pitting behaviour. Generally, higher chromium content results in better corrosion resistance. Although X35CrMo17-1 and $\mathrm{X} 5 \mathrm{CrNiCuNb16-4}$ show low surface corrosion rates, their resistance against local corrosion in CCS environment is not significantly better compared to the much less costly steels X20Cr13 and X46Cr13.
\end{abstract}

Index Terms - Corrosion, CCS, carbon storage, aquifer, heat treatment, fatigue, endurance limit.

\section{INTRODUCTION}

Carbon Capture and Storage (CCS) comprises of the capture of emission gasses e.g. from combustion processes of power plants and the compression into deep geological layers of a geological on-shore saline aquifer CCS-site [1]). The local corrosion of injection pipe steels may become an issue during compression of $\mathrm{CO}_{2}$ [2], [3]. In general, $\mathrm{CO}_{2}$-corrosion is sensitively dependent on alloy composition, contamination of alloy and media, temperature, $\mathrm{CO}_{2}$ partial pressure, flow conditions and protective corrosion scales [4], [5]-[10]. However, suitable heat treatment [8], [11] and martensitic microstructure [12] decrease the pitting potential. Pitting is reason for early failure of materials under cyclic load [13], [14].

Early pits on steel surfaces generally act as corrosion catalyser where corrosion layers grow slowly and usually showing the same corrosion products as surface layers [7]. The main corrosion product siderite $\mathrm{FeCO}_{3}$ [2] is formed locally on steels that are exposed to $\mathrm{CO}_{2}$-environment. Because the solubility of $\mathrm{FeCO}_{3}$ in water $\left(\mathrm{pK}_{\mathrm{sp}}=10.54\right.$ at $25^{\circ} \mathrm{C}$ [14]) is low the steel is susceptible to anodic dissolution. Most likely the initial formation of transient $\mathrm{Fe}(\mathrm{OH})_{2}$ [6], [11] leads to an increase of the local $\mathrm{pH}$ near the

Manuscript received December 4, 2017; revised February 5, 2018.

Anja Pfennig is with HTW University of Applied Sciences Berlin, Wilhelminenhofstraße 75 A, Gebäude C, 12459 Berlin, Germany (e-mail: anja.pfennig@htw-berlin.de)

Axel Kranzmann is with BAM Federal Institute of Materials Research and Testing, Unter den Eichen 87, 12205 Berlin, Germany (e-mail: axel.kranzmann@bam.de). hydroxide film. As a consequence an internal and external ferrous carbonate film precipitates [14] according to equations 1 to 6 :

$$
\begin{aligned}
& \mathrm{CO}_{2}(\mathrm{~g})+\mathrm{H}_{2} \mathrm{O}(\mathrm{l}) \rightarrow \mathrm{H}^{+}+\mathrm{HCO}_{3}{ }^{-}(\mathrm{aq}) \\
& \text { cathodic: } 2 \mathrm{HCO}_{3^{-}}+2 \mathrm{e}^{-} \rightarrow 2 \mathrm{CO}_{3}{ }^{2-}+\mathrm{H}_{2} \\
& \text { anodic: } \mathrm{Fe} \rightarrow \mathrm{Fe}^{2+}+2 \mathrm{e}^{-} \\
& \mathrm{Fe}^{2+}+\mathrm{CO}_{3}{ }^{2-} \rightarrow \mathrm{FeCO}_{3} \\
& \mathrm{Fe}^{2+}+2 \mathrm{HCO}_{3}^{-} \rightarrow \mathrm{Fe}\left(\mathrm{HCO}_{3}\right)_{2} \\
& \mathrm{Fe}\left(\mathrm{HCO}_{3}\right)_{2} \rightarrow \mathrm{FeCO}_{3}+\mathrm{CO}_{2}+\mathrm{H}_{2} \mathrm{O}
\end{aligned}
$$

Alloying elements [5], [8] as well as heat treatment [7], [11], [15] show significant influence on the local corrosion resistance of steels. Generally, high $\mathrm{Ni}$ - and Cr contents [9], [10] improve the overall corrosion resistance but retained austenite especially improves the pitting corrosion resistance [9]. Higher austenitizing temperature of martensitic steels [11] as well as higher annealing temperature of lean duplex stainless steels [8] also decrease the pitting potential. Due to reactive grain boundaries in martensitic microstructure $\mathrm{C}-\mathrm{Mn}$ (carbon) steels in a H2S-containing $\mathrm{NaCl}$ solution shows higher corrosion rates than ferritic or ferritic-bainitic microstructures [12].

Steels depicted in this study have either been used for CCS or show good potential to be used in geothermal environments. In this paper, we are presenting extended and compiled data of former work [3], [7], [13], [16]-[19].

\section{EXPERIMENTAL PROCEDURE}

\section{A. Steels}

Static corrosion tests at ambient pressure as well as at high pressure (100 bar) were carried out using samples of mild steels, martensitic and duplex stainless steels (Table I-IV):

1. AISI 420 (X20Cr13, 1.4021) (Table I)

2. AISI 420C (X46Cr13, 1.4043) (Table II)

3. No AISI (X35CrMo17, 1.4122) (Table III)

\section{AISI 630 (X5CrNiCuNb 16-4, 1.4542) (Table IV)}

In order to confirm the material's chemical composition, samples were analyzed via spark emission spectrometry SPEKTROLAB $\mathrm{M}$ and by Electron Probe Microanalyzer 
JXA8900-RLn (Table I-IV).

TABLE I: CHEMICAL COMPOSITION OF 1.4021 (X20CR13, AISI 420A), (IN MASS PERCENT).

\begin{tabular}{llllll}
\hline Elements & $\mathrm{C}$ & $\mathrm{Si}$ & $\mathrm{Mn}$ & $\mathrm{P}$ & $\mathrm{S}$ \\
\hline acc standard $^{\mathrm{a}}$ & $0.17-0.25$ & $<1.00$ & $\leq 1.00$ & $\leq 0.045$ & $\leq 0.03$ \\
analysed $^{\mathrm{b}}$ & 0.22 & 0.39 & 0.32 & 0.007 & 0.006 \\
\hline & & & & & \\
\hline Elements & $\mathrm{Cr}$ & $\mathrm{Mo}$ & $\mathrm{Ni}$ & $\mathrm{Co}$ & $\mathrm{Fe}$ \\
\hline acc standard $^{\mathrm{a}}$ & $12.0-14.0$ & & & & $0.20-0.45$ \\
analysed $^{\mathrm{b}}$ & 13.3 & - & 0.123 & - & rest \\
\hline
\end{tabular}

a) elements as specified according to DIN EN 10088-3 in \%

b) spark emission spectrometry

TABLE II: CHEMICAL COMPOSITION OF 1.4043 (X46CR13, AISI 420C), (IN

\begin{tabular}{llllll}
\multicolumn{5}{c}{ MASS PERCENT). } \\
\hline Elements & $\mathrm{C}$ & $\mathrm{Si}$ & $\mathrm{Mn}$ & $\mathrm{P}$ & $\mathrm{S}$ \\
\hline acc standard $^{\mathrm{a}}$ & $0.42-0.5$ & $<1.00$ & $\leq 1.00$ & $\leq 0.045$ & $\leq 0.03$ \\
analysed $^{\mathrm{b}}$ & 0.46 & 0.25 & 0.45 & 0.018 & 0.003 \\
\hline Elements $^{\text {Cr }}$ & $\mathrm{Mo}$ & $\mathrm{Ni}$ & $\mathrm{Co}$ & $\mathrm{Fe}$ \\
\hline acc standard $^{\mathrm{a}}$ & $12.5-14.5$ & & & & $0.20-0.45$ \\
analysed $^{\mathrm{b}}$ & 13,39 & 0.03 & 0.13 & 0.03 & 85.4
\end{tabular}

c) elements as specified according to DIN EN 10088-3 in \%

d) spark emission spectrometry

These two steels are well known in geothermal energy production, where they may be used as piping, shafts, or axles in pumps [2], [18]. These alloys contain $13 \%$ chromium, but the carbon content differs significantly as the carbon content of 1.4034 ( 0.46 mass- $\%$ C) is more than twice as high as that of 1.4020 (0.2 mass-\% C). The common assumption and observation is that carbon increases the corrosion rate.

TABLE III: CHEMICAL COMPOSITION OF 1.4122 (X35CRMo17), (IN MASS

\begin{tabular}{llllll}
\multicolumn{5}{c}{ PERCENT $)$} \\
\hline Elements & $\mathrm{C}$ & $\mathrm{Si}$ & $\mathrm{Mn}$ & $\mathrm{P}$ & $\mathrm{S}$ \\
\hline acc standard $^{\mathrm{a}}$ & $0.33-0.45$ & $<1.00$ & $\leq 1.00$ & $\leq 0.045$ & $\leq 0.03$ \\
\hline Elements & $\mathrm{Cr}$ & $\mathrm{Mo}$ & $\mathrm{Ni}$ & $\mathrm{Co}$ & $\mathrm{Fe}$ \\
\hline acc standard $^{\mathrm{a}}$ & $15.5-17.5$ & $0.8-1.3$ & $\leq 1.00$ & & $0.20-0.45$
\end{tabular}

a) elements as specified according to DIN EN 10088-3 in \%

TABLE IV: CHEMICAL COMPOSITION OF 1.4542 (X5CRNICUNB16-4, AISI 630), (IN MASS PERCENT).

\begin{tabular}{llllll}
\multicolumn{7}{c}{ 630), (IN MASS PERCENT). } \\
\hline Elements & $\mathrm{C}$ & $\mathrm{Si}$ & $\mathrm{Mn}$ & $\mathrm{P}$ & $\mathrm{S}$ \\
\hline acc standard $^{\mathrm{a}}$ & $\leq 0.07$ & $\leq 0.70$ & $\leq 1.50$ & $\leq 0.04$ & $\leq 0.015$ \\
analysed $^{\mathrm{b}}$ & 0.03 & 0.42 & 0.68 & 0.018 & 0.002 \\
\hline \hline Elements & $\mathrm{Cr}$ & $\mathrm{Mo}$ & $\mathrm{Ni}$ & $\mathrm{Cu}$ & $\mathrm{Nb}$ \\
\hline acc standard $^{\mathrm{a}}$ & $15.0-$ & $\leq 0.60$ & $3.00-$ & $3.00-$ & $0.20-$ \\
& 17.0 & & 5.00 & 5.00 & 0.45 \\
analysed $^{\mathrm{b}}$ & 15.75 & 0.11 & 4.54 & 3.00 & 0.242
\end{tabular}

a) elements as specified according to DIN EN 10088-3 in \%

b) spark emission spectrometry

1.4542 stainless steel (AISI 630, X5CrNiCuNb16-4) is a precipitation hardening martensitic stainless steel with about $3 \%$ copper with small size copper distributed in the matrix ensuring the precipitation hardening mechanism. Islands of niobium and copper carbides are embedded within the microstructure of 1.4542 characterized by layers of the martensitic matrix of bcc-structure. This increases the strength of the material and ensures excellent mechanical properties as well as good corrosion resistance. But, 1.4542 is known to be susceptible towards stress corrosion cracking (SCC) and less corrosion resistant compared to its solution treated state with lower strength [16]-[18].

\section{B. Aquifer Water}

To simulate in-situ geothermal condition the geothermal aquifer water (as known to be similar to the Stuttgart Aquifer [20], [21]: $\mathrm{Ca}_{2}{ }^{+}: 1760 \mathrm{mg} / \mathrm{L}, \mathrm{K}^{2+}: 430 \mathrm{mg} / \mathrm{L}, \mathrm{Mg}^{2+}: 1270$ $\mathrm{mg} / \mathrm{L}, \quad \mathrm{Na}^{2+}: 90100 \mathrm{mg} / \mathrm{L}, \mathrm{Cl}^{-}: 143,300 \mathrm{mg} / \mathrm{L}, \mathrm{SO}_{4}{ }^{2-}: 3600$ $\mathrm{mg} / \mathrm{L}, \mathrm{HCO}_{3}^{-}: 40 \mathrm{mg} / \mathrm{L}$ ) was synthesized in a strictly orderly way to avoid precipitation of salts and carbonates.

\section{Corrosion Experiments}

Laboratory scale exposure tests in $\mathrm{CO}_{2}$-saturated aquifer brine and water saturated $\mathrm{CO}_{2}$ were carried out using coupons of the steel qualities that may be used as injection pipe. Therefore steel samples made of as received and thermally treated specimens with $8 \mathrm{~mm}$ thickness, $20 \mathrm{~mm}$ width, $50 \mathrm{~mm}$ length were used (Fig. 1). To gain martensitic microstructure with sufficient hardness and toughness prior to exposure heat treatment was done following commonly used protocols [7], [16], [17]. A hole of $3.9 \mathrm{~mm}$ diameter was used for sample positioning. Samples of each base metal were positioned within the vapour phase and within the liquid phase.
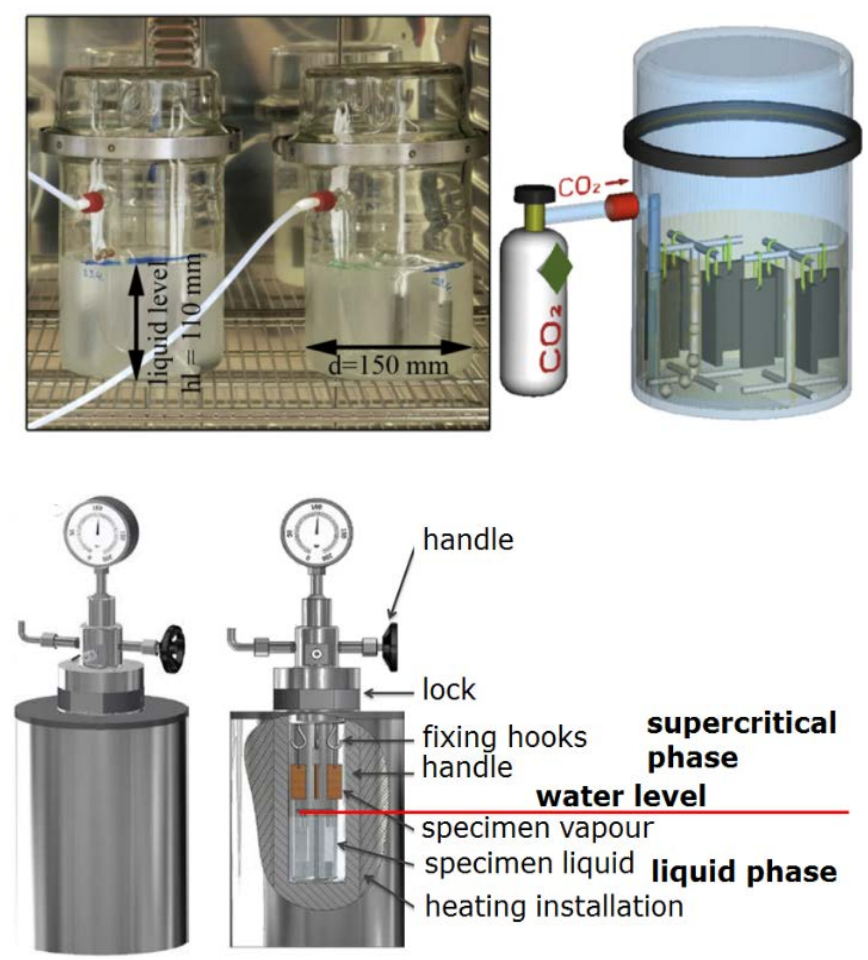

Fig. 1. Reaction vessels and experimental set up [7], [17].

Flow control (3 NL/h) of the technical $\mathrm{CO}_{2}$ (purity 99.995 vol.-\%)) into the brine at ambient pressure was done by a capillary meter GDX600_man by QCAL Messtechnik GmbH, Munich. The exposure of the samples between $700 \mathrm{~h}$ to 8000 $\mathrm{h}$ was disposed in reaction vessels according to the conditions at the geological site at $60{ }^{\circ} \mathrm{C}$ at ambient pressure - each material in a separated reaction vessel [3] and at 100 bar [7], [13], [16] (Fig. 1).

Before the corrosion tests the surfaces of the steels were 
activated by grinding with SiC-Paper down to $120 \mu \mathrm{m}$ under water. After the corrosion tests, one half of the samples were cut for scale analysis with the corrosion layer attached and the other half was prepared for kinetic analysis after the scale was etched. The samples were descaled by exposure to $37 \%$ $\mathrm{HCl}$. Then parts of the samples were embedded in a cold resin (Epoxicure, Buehler), cut and polished first with SiC-Paper from $180 \mu \mathrm{m}$ to $1200 \mu \mathrm{m}$ under water and then finished with diamond paste $6 \mu \mathrm{m}$ and $1 \mu \mathrm{m}$.

\section{Analysis}

Different light optical and electron microscopy techniques were performed on specimens to investigate the layer structures and morphology of the samples. X-ray diffraction was carried out in a URD-6 (Seifert-FPM) with CoK $\alpha$-radiation with an automatic slit adjustment, step $0.03^{\circ}$ and count 5 sec. Kinetics of the corrosion were determined by the corrosion rates which were calculated via mass change of the samples before and after corrosion testing according to DIN 50905 part 1-4. To characterize the pitting corrosion, 3-D-images were realized by the double optical system Microprof TTV by FRT. Kinetics of the corrosion were determined by the corrosion rates which were calculated via mass change of the samples before and after corrosion testing according to DIN 50905 part 1-4 and using the semi-automatic analyzing program Analysis Docu ax-4 by Aquinto.
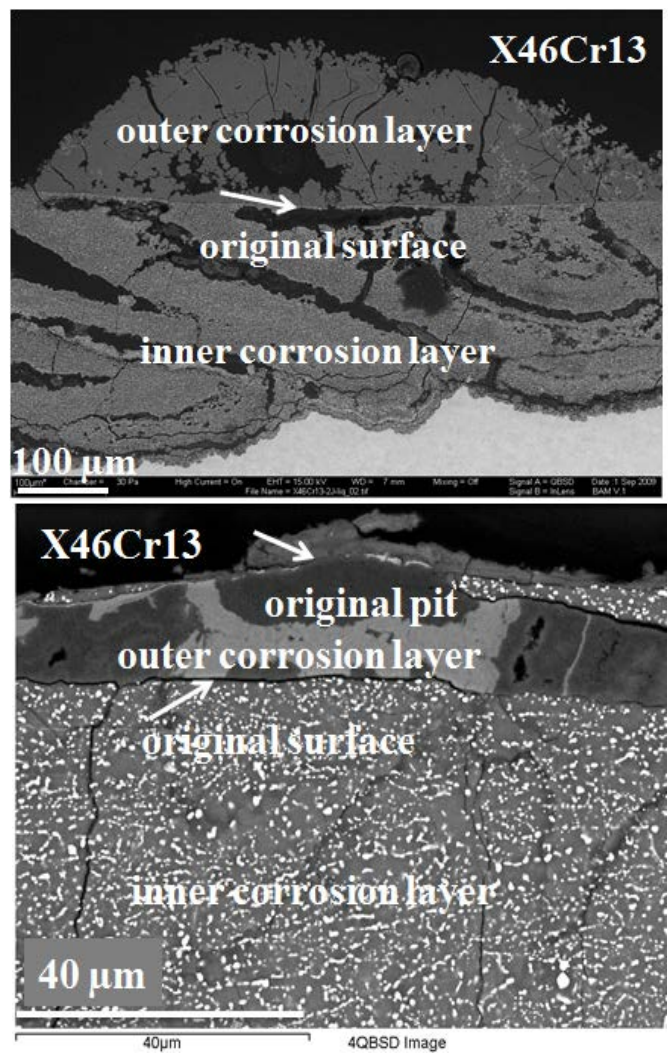

Fig. 2. SEM micrographs of X46Cr13 after 17,200 hours of exposure at $60{ }^{\circ} \mathrm{C}$ and 100 bar to water saturated supercritical $\mathrm{CO}_{2}$ clearly showing inner and outer corrosion layer.

\section{RESUlTS AND DiscUSSION}

In general injecting $\mathrm{CO}_{2}$ into saline aquifer storages places a water free surrounding at the bottom of the borehole at the disposal, due to the supercritical or liquid $\mathrm{CO}_{2}$ replacing the water as a result of the injection pressure. But in the case of intermissions of the injection process the water level may rise within the injection pipe leading to the three phase boundary (water, metal, gas/supercritical) and as a consequence to the typical corrosion phenomena. Therefore, immersion tests at $60^{\circ} \mathrm{C}$ at ambient pressure and at 100 bar were performed in saline aquifer water (Stuttgart Aquifer and Northern German Basin) at $60{ }^{\circ} \mathrm{C}$ using technical $\mathrm{CO}_{2}$ to model the CCS-environment. Local corrosion in $\mathrm{CO}_{2}$-saturated artificial saline water environment as well as in water-saturated (supercritical) $\mathrm{CO}_{2}$ give a good estimation of the reliability of steels used as injection pipe. Main corrosion products covering pits after static corrosion tests at ambient pressure as well as 100 bar were $\mathrm{FeCO}_{3}$ and $\mathrm{FeOOH}$ for all steel qualities.

On martensitic stainless steels X46Cr13 and X20Cr13 initial pits grow very quickly to form a discontinuous surface layer that can be divided into an inner corrosion layer (dissolution of base metal) and outer corrosion layer (oxide growth on metal surface) then covering the entire surface of the sample (Fig. 2 and Fig. 3).

The internal and external corrosion layer grow depending on the various carbon and oxygen partial pressures [7], [13]. Due to mismatches of thermal expansion coefficients and large differences in surface morphologies the corrosion layer detaches in lateral direction once a critical thickness of the corrosion layer within a pit is exceeded (Fig. 3).

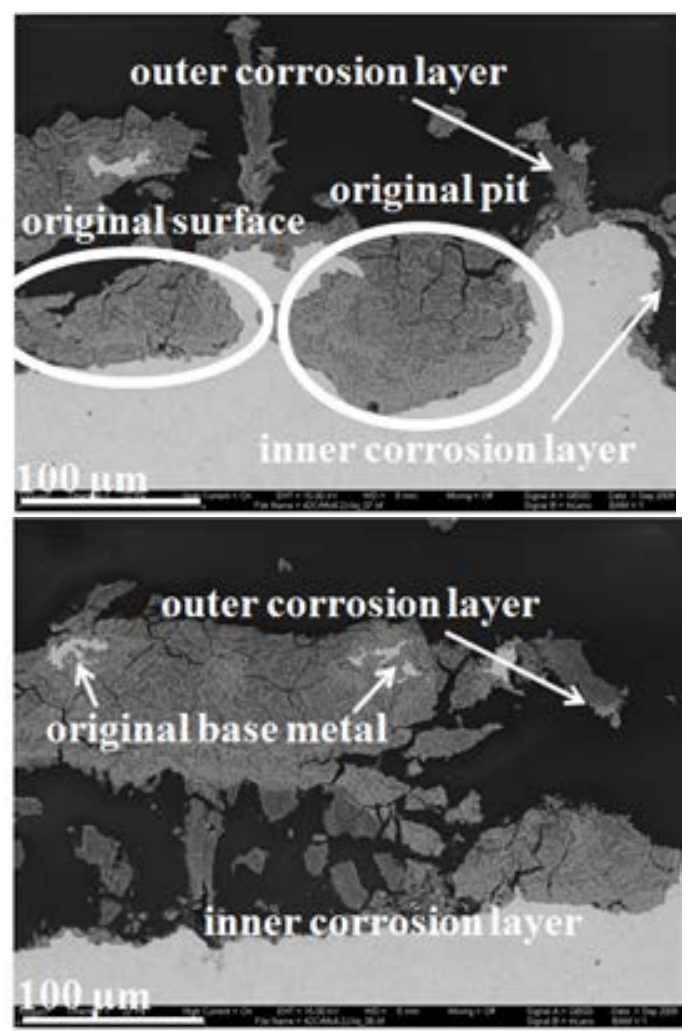

Fig. 3. SEM micrographs of detached corrosion layer on alloyed steels after 17200 hours of exposure at $60^{\circ} \mathrm{C}$ and 100 bar to water saturated supercritical $\mathrm{CO}_{2}$.

This local surface degradation is enhanced because oxygen vacancies as a result from the equations (1) to (6) consolidate and condense at the hydroxide/brine interface. The possible initial formation of transient $\mathrm{Fe}(\mathrm{OH})_{2}$ [6], [11] is described by equations (7) to (9). Due to the oxygen vacancies $\mathrm{pH}$ and lattice changes may occur as one of the initial degradation 
steps. Wei et al. [10] have discussed the dependence on the anionic concentration of the consecutive reactions. As a consequence the siderite detaches from the transient hydroxide film described in detail by various authors [7], [9], [13] with vacancies generated by carbonate ions being the main cause for the precipitation of further oxygen vacancies catalyzing the reaction series:

$$
\mathrm{Fe}+2 \mathrm{H}_{2} \mathrm{O} \rightarrow\left[\mathrm{Fe}(\mathrm{OH})_{2}\right] \text { ads }+2 \mathrm{H}^{+}+2 \mathrm{e}^{-}
$$

$\left[\mathrm{Fe}(\mathrm{OH})_{2}\right]$ ads $+\mathrm{H}_{2} \mathrm{O} \rightarrow$ alpha-FeOOH$+3 \mathrm{H}^{+}+3 \mathrm{e}^{-}$

$$
\left[\mathrm{Fe}(\mathrm{OH})_{2}\right] \text { ads }+\left[\mathrm{H}_{2} \mathrm{CO}_{3}\right] \text { ads } \rightarrow \mathrm{FeCO}_{3}+2 \mathrm{H}_{2} \mathrm{O}
$$

The flowing corrosive media removes the remaining film causing the pit to grow wider and eventually cover the entire surface.

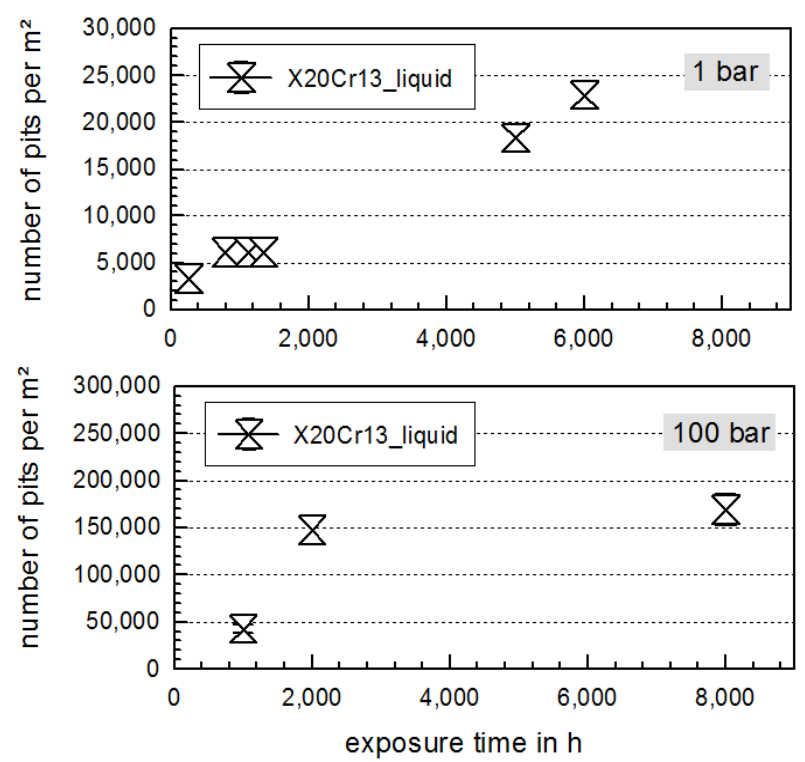

Fig. 4. Number of pits of X20Cr13 in the liquid phase after $6000 / 8000$ h of exposure to aquifer brine water at $60{ }^{\circ} \mathrm{C}$ and ambient pressure as well as at 100 bar.
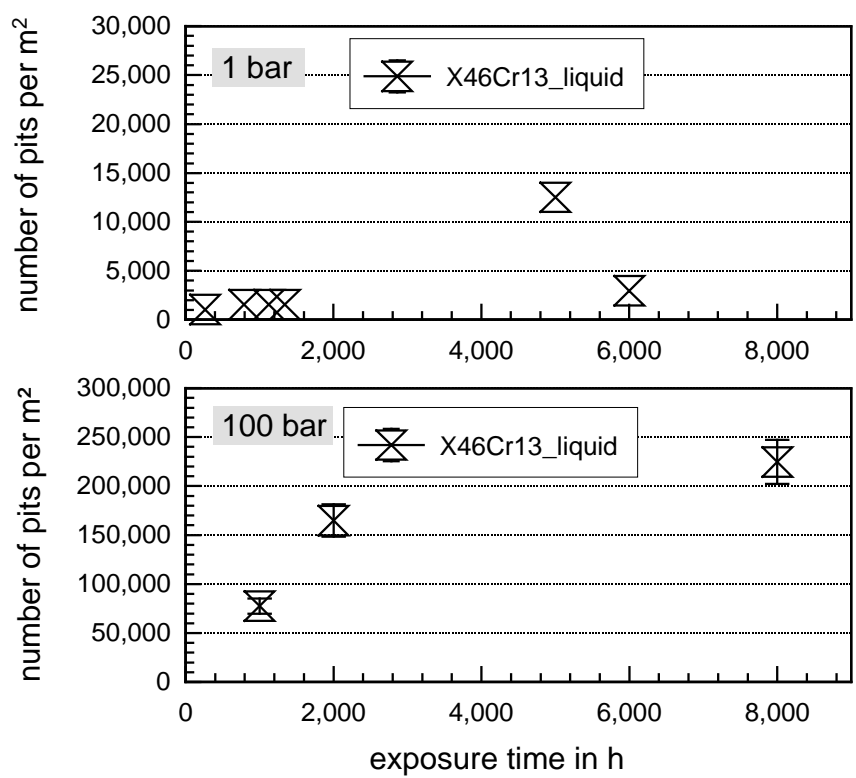

Fig. 5. Number of pits of X46Cr13 in the liquid phase after $6000 / 8000 \mathrm{~h}$ of exposure to aquifer brine water at $60^{\circ} \mathrm{C}$ and ambient pressure as well as at 100 bar.
Steel qualities investigated showed distinct local corrosion phenomena (Fig. 4 to Fig. 7) with generally higher number of pits under aquifer water conditions. Also a higher chromium content of the steels leads to a higher number of pits per m2. (Note, that these steels only show very little surface corrosion but therefore are highly susceptible to local corrosion). The number of pits formed at 100 bar either in $\mathrm{CO}_{2}$-saturated aquifer water (liquid phase) in water saturated $\mathrm{CO}_{2}$ (supercritical/vapour phase) exceeds those formed at ambient pressure by a factor of 10 . Because after similar exposure times the corrosion scale is much thicker when precipitated at ambient pressure and therefore complicates analysis. Moreover, kinetics at 100 bar are faster, pressing $\mathrm{CO}_{2}$ and water onto the metal`s surface resulting in a lower $\mathrm{pH}$ and faster local degradation of the steel [17].

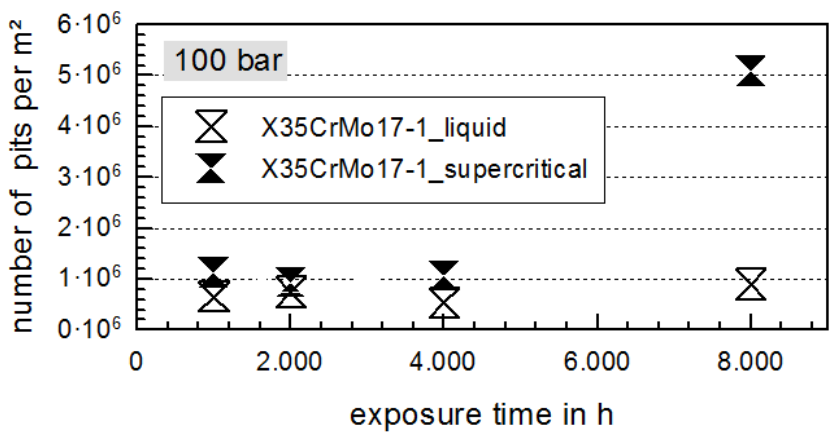

Fig. 6. Number of pits of X35CrMo17-1 in the liquid phase after 6000/8000 $\mathrm{h}$ of exposure to aquifer brine water at $60^{\circ} \mathrm{C}$ and 100 bar.
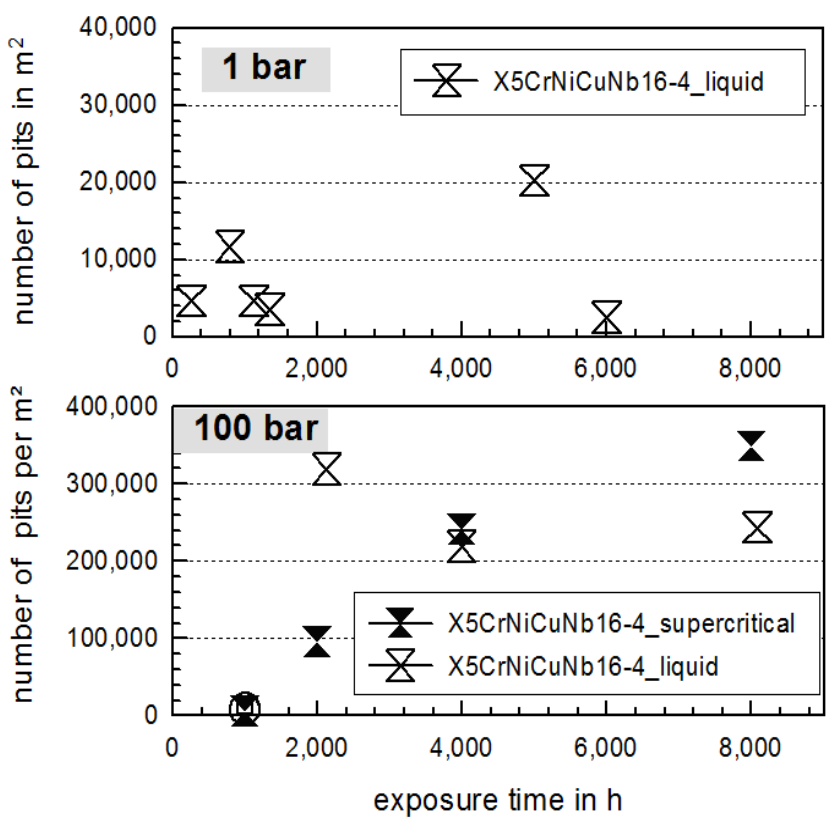

Fig. 7. Number of pits of $\mathrm{X} 5 \mathrm{CrNiCuNb} 16-4$ in the liquid phase after $6000 / 8000 \mathrm{~h}$ of exposure to aquifer brine water at $60^{\circ} \mathrm{C}$ and ambient pressure as well as at 100 bar.

In general X20Cr13 and X46Cr13 are not suitable for long term CCS application due to their high surface corrosion rates [7] and also because of the unpredictable local corrosion. Although $\mathrm{X} 5 \mathrm{CrNiCuNb} 16-4$ is known for fairly good corrosion resistance, especially stress corrosion resistance in CCS atmosphere the steel developed pitting corrosion in both atmospheres, water saturated supercritical $\mathrm{CO}_{2}$ and $\mathrm{CO}_{2}$ saturated aquifer water (Fig. 7). Despite the alloying elements ensuring good surface corrosion resistance, this 
steel shows a rather high number of pits per m2. The number of pits after $8000 \mathrm{~h}$ are $50000-260000$ in the liquid phase and from 250000 to more than 1000000 in the supercritical phase. Pit depths measured after exposure at 100 bar and $60{ }^{\circ} \mathrm{C}$ are about 10-250 $\mu \mathrm{m}$ [16]. The lower number of pits at ambient pressure is due to the higher surface corrosion rate and rather large areas on the sample covered with siderite. Here pits have been consolidated and therefore counted as either single pit or measured as surface corrosion. [16]. Comparing all steel qualities at in-situ environments according to onshore CCS sites (100 bar) X35CrMo17 promises the best corrosion resistance considering local corrosion. This is clearly related to the high chromium and molybdenum content and is in good agreement with PREN (pitting resistance numbers) predicting the susceptibility to local corrosion. However, pitting is a statistical phenomenon and therefore steels need to be monitored closely.

\section{CONCLUSION}

In general injecting $\mathrm{CO}_{2}$ into saline aquifer storages places a water free surrounding at the bottom of the borehole at the disposal, due to the supercritical or liquid $\mathrm{CO}_{2}$ replacing the water as a result of the injection pressure. But in the case of intermissions of the injection process the water level may rise within the injection pipe leading to the three phase boundary (water, metal, gas/supercritical) and as a consequence to the typical corrosion phenomena. Therefore, immersion tests at $60{ }^{\circ} \mathrm{C}$ at ambient pressure and at 100 bar were performed in saline aquifer water (Stuttgart Aquifer and Northern German Basin) at $60{ }^{\circ} \mathrm{C}$ using technical $\mathrm{CO}_{2}$ to model the CCS-environment. Local corrosion in $\mathrm{CO}_{2}$-saturated artificial saline water environment as well as in water-saturated (supercritical) $\mathrm{CO}_{2}$ give a good estimation of the reliability of steels used as injection pipe. Main corrosion products covering pits after static corrosion tests at ambient pressure as well as 100 bar were $\mathrm{FeCO}_{3}$ and $\mathrm{FeOOH}$ for all steel qualities. The carbon content does not show significant influence on the local corrosion. But higher chromium content results in better corrosion resistance. Although X35CrMo17-1 and X5CrNiCuNb16-4 show low surface corrosion rates, their resistance against local corrosion in CCS environment is not significantly better compared to the much less costly steels X20Cr13 and X46Cr13. Steels are unsuitable for its use in pressure vessel applications if the corrosion rate exceeds $0,1 \mathrm{~mm} /$ year. Reliable corrosion rates and lifetime predictions regarding pit corrosion for all steels in CCS technology are not possible due to the statistical nature of these particular local corrosion phenomena. According to DIN 6601 42CrMo4, X20Cr13 and X46Cr13 would be unsuitable for pressure vessel application, when being surrounded by the $\mathrm{CO}_{2}$-saturated brine at ambient pressure.

\section{ACKNOWLEDGMENT}

This work was supported by the FNK (Fachkonferenz für wissenschaftliche Nachwuchskräfte) of the Applied University of Berlin, HTW and by IMPACT (EU-Project EFRE 20072013 2/21).

\section{REFERENCES}

[1] M. R. van den Broek, R. E. Hoefnagels, W. Turkenburg, and E. Faaij, "Effects of technological learning on future cost and performance of power plants with $\mathrm{CO}_{2}$ capture," in Projects Costs of Generating Electricity, Progress in Energy and Combustion Science, pp. 177-187, 2010.

[2] S. Nešić, "Key issues related to modelling of internal corrosion of oil and gas pipelines - A review," Corrosion Science, vol. 49, pp. 4308-4338, 2007.

[3] A. Pfennig and A. Kranzmann, "Reliability of pipe steels with different amounts of $\mathrm{C}$ and $\mathrm{Cr}$ during onshore carbon dioxide injection," International Journal of Greenhouse Gas Control, vol. 5, pp. 757-769, 2011.

[4] H. Zhang, Y. L. Zhao, and Z. Jiang, "Effects of temperature on the corrosion behaviour of $13 \mathrm{Cr}$ martensitic stainless steel during exposure to $\mathrm{CO}_{2}$ and $\mathrm{Cl}^{-}$environment," Material Letters, vol. 59, pp. 3370-3374, 2005.

[5] J. N. Alhajji and M. R. Reda, "The effect of alloying elements on the electrochemical corrosion of low residual carbon steels in stagnant $\mathrm{CO}_{2}$-saturated brine,” Corrosion Science, vol. 34, pp. 1899-1911, 1993.

[6] Y.-S. Choi and S. Nešić, "Corrosion behaviour of carbon steel in supercritical $\mathrm{CO}_{2}$-water environments," in Proc. NACE Corrosion Conference and Expo, New Orleans, Louisiana, USA, March 16-20, 2008.

[7] A. Pfennig, P. Zastrow, and A. Kranzmann, "Influence of heat treatment on the corrosion behaviour of stainless steels during $\mathrm{CO}_{2}$-sequestration into saline aquifer," International Journal of Green House Gas Control, vol. 15, pp. 213-224, 2013.

[8] Ş. Bülbül and Y. Sun, "Corrosion behaviours of high Cr-Ni cast steels in the HCl solution,” Journal of Alloys and Compounds, vol. 598, pp. 143-147, 2010.

[9] J. Banaś, U. Lelek-Borkowska, B. Mazurkiewicz, W. Solarski, “Effect of $\mathrm{CO}_{2}$ and $\mathrm{H}_{2} \mathrm{~S}$ on the composition and stability of passive film on iron alloy in geothermal water," Electrochimica Acta, vol. 52, pp. 5704-5714, 2007.

[10] L. Wei, X. Pang, C. Liu, and K. Gao, "Formation mechanism and protective property of corrosion product scale on X70 steel under supercritical $\mathrm{CO}_{2}$ environment," Corrosion Science, vol. 100, pp. 404-420, 2015.

[11] A. N. Isfahany, H. Saghafian, and G. Borhani, "The effect of heat treatment on mechanical properties and corrosion behaviour of AISI420 martensitic stainless steel,” Journal of Alloys and Compounds, vol. 509, pp. 3931-3936, 2011.

[12] M. A. Lucio-Garciaa, J. G. Gonzalez-Rodrigueza, M. Casalesc, L. Martinez, J. G. Chacon-Navaa, M. A. Neri-Floresa, and A. Martinez-Villafañea, "Effect of heat treatment on $\mathrm{H}_{2} \mathrm{~S}$ corrosion of a micro-alloyed C-Mn steel,” Corrosion Science, vol. 51, pp. 2380-2386, 2009.

[13] A. Pfennig, R. Wiegand, M. Wolf, and C.-P. Bork, "Corrosion and corrosion fatigue of AISI 420C (X46Cr13) at $60{ }^{\circ} \mathrm{C}$ in $\mathrm{CO}_{2}$-saturated artificial geothermal brine,” Corrosion Science, vol. 68, pp. 134-143, 2013.

[14] J. Han, Y. Yang, S. Nešić, and B. N. Brown, "Roles of passivation and galvanic effects in localized $\mathrm{CO}_{2}$ corrosion of mild steel," in Proc. NACE Corrosion 2008, New Orleans, Louisiana, USA, March 16-20, 2008.

[15] J. Wang and H. Zou, "Relationship of microstructure transformation and hardening behavior of type 630 stainless steel,” J. Univ. Sci. Tech. Beijing, vol. 3, pp. 213-221, 2006.

[16] A. Pfennig, H. Wolthusen, and A. Kranzmann, "Unusual corrosion behavior of 1.4542 exposed a laboratory saline aquifer water CCS-environment,” Energy Procedia, vol. 114, pp. 5229-5240, 2007.

[17] M. Wolf, R. Afanasiev, Th. Böllinghaus, and A. Pfennig, "Investigation of corrosion fatigue of duplex steel X2CrNiMoN22 53 exposed to a geothermal environment under different electrochemical conditions and load types," Energy Procedia, vol. 114, pp. 5337-5345, 2017.

[18] A. Pfennig, H. Wolthusen, M. Wolf, and A. Kranzmann, "Effect of heat treatment of injection pipe steels on the reliability of a saline aquifer water CCS-site in the Northern German Basin,” Energy Procedia, vol. 63, pp. 5762-5772, 2014.

[19] A. Pfennig and A. Kranzmann, "Effect of $\mathrm{CO}_{2}$ and pressure on the stability of steels with different amounts of Chromium in saline water," Corrosion Science, vol. 65, pp. 441-452, 2012.

[20] A. Förster B. Norden, K. Zinck-Jørgensen, P. Frykman, K, Kulenkampff, E. Spangenberg, J. Erzinger, M. Zimmer, J. Kopp, G. Borm, C. Juhlin, C. Cosma, and S. Hurter, "Baseline characterization 
of the $\mathrm{CO}_{2}$ SINK geological storage site at Ketzin, Germany," Environmental Geosciences, vol. 13, pp. 145-161, 2006.

[21] A. Förster, R. Schöner, H.-J. Förster, B. Norden A.-W. Blaschke, J. Luckert, G. Beutler, R. Gaupp, and D. Rhede, "Reservoir characterization of a $\mathrm{CO}_{2}$ storage aquifer: The upper triassic stuttgart formation in the Northeast German Basin,” Marine and Petroleum Geology, vol. 27, pp. 2156-2172, 2010.

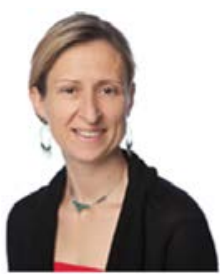

A. Pfennig was born in Büdelsdorf, Germany in April 1970. She studied minerology at the Rheinische Friedrich Wilhelms University Bonn, Germany, where she graduated in 1997. Her Ph.D in the field of ceramic moulds for liquid metal casting was earned in 2001 from the Friedrich Alexander University of Erlangen, Germany. She then worked for Siemens Energy in charge of ceramic shields and transferred to Berlin in 2008 where she currently teaches material science for engineering students at the Applied University Berlin, HTW. A. Pfennig research interest and expertise is in the field of corrosion fatigue of materials at high temperature and high pressure simulating geothermal environments.

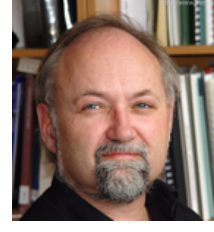

A. Kranzmann was born in Bad-Bibra, Germany in 1956. He studied physics at the University of Cologne, Germany and finished his Ph.D in 1988 in the field of metallurgy at the MPI for Metals Research, Germany, where he worked from 1986 - 1991. He then transferred to ABB AG in Heidelberg as head of section in charge of materials- and surface technology and later R\&D coordination manager of ABB Germany until 2001. From then on and currently he is group leader "microstructure of materials" at the BAM, Federal Institute for Research and Development. A. Kranzmann research interest and expertise is in the field of high temperature and gas corrosion, ageing of metals, experimental simulation of high-temperature processes and research of surface topology. 